\title{
Meta
}

Journal des traducteurs

Translators' Journal

\section{WILSON, Rita and GERBER, Leah (2012): Creative Constraints: Translation and Authorship. Clayton, Victoria (Australia): Monash University Press, 166 p.}

\section{Eusebio V. Llácer}

Volume 59, numéro 2, août 2014

URI : https://id.erudit.org/iderudit/1027486ar

DOI : https://doi.org/10.7202/1027486ar

Aller au sommaire du numéro

Éditeur(s)

Les Presses de l’Université de Montréal

ISSN

0026-0452 (imprimé)

1492-1421 (numérique)

Découvrir la revue

Citer ce compte rendu

Llácer, E. V. (2014). Compte rendu de [WILSON, Rita and GERBER, Leah (2012): Creative Constraints: Translation and Authorship. Clayton, Victoria (Australia): Monash University Press, 166 p.] Meta, 59(2), 460-462.

https://doi.org/10.7202/1027486ar d'utilisation que vous pouvez consulter en ligne.

https://apropos.erudit.org/fr/usagers/politique-dutilisation/ 
The seventeen teaching units are organised in two main sections: non-specialised translation (Units 1-13) and introduction to specialised translation (Units 14-17). The first section starts with a diagnostic evaluation task in Unit 1 and ends with a self-evaluation task in Unit 17. The author's approach to translator training and evaluation is based on her research to develop measuring instruments for translation competence acquisition: "(i) to measure notions about translation, (ii) to measure students' behaviour when faced with translation problems, and (iii) to measure errors" (Orozco and Hurtado-Albir 2002). The diagnostic tool used in Unit 1 was extensively tested by the author and validated by teachers in other translation faculties. The test is made up of three parts: (i) a questionnaire on general translation concepts; (ii) a translation; (iii) a questionnaire on the translation in the format of a guided retrospective TAP. The self-evaluation task in the last unit is one of many formative evaluation activities in the book. In Unit 17, students are asked to revisit and reflect on their answers to the first part of the diagnostic questionnaire.

The objective of the tasks in Units 2 to 4 is to start students thinking about some basic translation concepts, such as translation as a communication act, as a cognitive process, equivalence, the translation unit. Teachers often avoid using textbooks in translation classes because the texts are out-of-date. In this book, the texts are well selected to illustrate the objectives of each task, provoke debate and reflect the realities of the translation profession, but they are also selected to age well. Even the two texts on machine translation and human translation, dated 2003 and 2010 (p.15-19), remain relevant in 2013 and can easily be followed up or replaced by a more recent text of the same genre.

The tasks in Unit 5 take the students through all the steps in the translation process, from the translation initiator to the revision of the target text. It includes useful models or checklists: to analyse source and target texts; to identify problems at different stages of the process; to discover strategies for solving translation problems; to revise the translation. The following units (6-12) focus on different aspects of the process: comprehension, documentation, contrastive rhetoric, the language of the translation, translation methods, cultural contrasts, new technologies, etc.

The next three units (14-16) provide an introduction to specialised translation: the process, planning documentation, techniques for specialised terminology. The twelve specialised texts worked on in these units include localisation, economic, technical, medical and legal genres. These texts and tasks show the author's experi- ence as a professional translator in these fields. The tasks related to legal translation reflect the author's research in this field and, in particular, documentation for legal translators (Orozco and Sánchez-Gijón, 2011).

This is a book with solid foundations in teaching and research experience, enlivened by the author's creativity and capacity to put herself in the shoes of the learner.

Allison Beeby Lonsdale Universitat Autònoma de Barcelona. Barcelona, Spain

\section{REFERENCES}

Orozco, Mariana et Hurtado Albir, Amparo (2002): Measuring Translation Competence Acquisition. Meta. 47(3):375-402.

Orozco, Mariana et Sánchez-Gijón, Pilar (2011): New Resources for Legal Translators. Perspectives. 19(1):25-44.

Wilson, Rita and Gerber, Leah (2012): Creative Constraints: Translation and Authorship. Clayton, Victoria (Australia): Monash University Press, $166 \mathrm{p}$.

Creative Constraints: Translation and Authorship, edited by Rita Wilson and Leah Gerber is structured in three parts: Transcreation and Selftranslation, Creative Practice, and Translations. The first part is in turn divided into five theoretical chapters, while the second offers three practical ones, and finally the third comprises three translations. As the editors write in the introduction, "this collection of essays aims to illustrate the parallel and overlapping discourses within the cognate areas of literary studies, creative writing and translation studies." They also state that some of the contributions in this volume were written by participants of Translated!, the inaugural Literary Translation Summer School, run by Monash University in collaboration with the British Centre for Literary Translation in February 2011.

The first chapter notes that refraction is a useful concept in examining how texts can veer off in different directions from the original, how they adapt to new forms and meanings, and how English speakers can read something different from the novelistic canon in the West. The explanations are generally quite intuitive and reasonable, especially in the section Optical Illusions, devoted to translation as refraction of literary works. Valerie Henitiuk uses the metaphor of the telescope to explain how translation allows us to observe a brighter and clearer image of the literary work by means of refraction. 
In chapter two we read that the Spanish poet Leopoldo Panero defines the notion of "per-version" as the literary re-creation and proliferation, at least equal in quality to the "original" creation. Ramón López Castellanos's chapter offers a wise and well-documented view of Spanish poète maudit Panero's vision of translation as a possible but perverted activity where translation aims to leave only the original sense intact so as to produce a similar aesthetic effect.

On the other hand, Rita Wilson explores the process of self-translation in four contemporary Italophone women writers. She argues that an examination of the self-translating process can help in understanding cultural differences and demonstrates the potential opening up of new sources of literary creativity by renewing literary language and traditions. Wilson's insightful notion of multilingual creation as a means to "enter, know and become the Other," helps us considerably to define how our experiences can be translated into knowledge for other culturally different people.

Finally, poet and literary translator Ouyang $\mathrm{Yu}$ feels that self-translation has not received adequate attention from publishing companies and scholars, and that fiction and poetry translated from Chinese into English is vital to the survival of the writer-translation, while Lia Hills contends that the very process of self-translation by an author writing amounts to a translation of the "self."

The second section, Creative Practice, affords us the most original and real accounts of the practice of translation. In her article about her own translation into Italian of Alice Pung's Unpolished Gem, Adele D'Arcangelo begins by offering BoaseBeier and Holman's (1999: 6) quote summarizing the intertextual and extratextual constraints to which all creative authors, including translators, are bound. Perhaps the best contribution of D'Arcangelo is the demonstration in her own work of the Bassnett and Bush's (2006: 8) notion that translators inhabit an "in-betweenness," an undefinable "space of hybridity" between the source language (SL) and the target language (TL), the paradigm of the process that produces intercultural clashes and contaminations, which helps re-establish cross-linguistic perspectives while also offering multicultural encounters for potential target readers.

On the other hand, Jean Anderson's comments on her translation of Moetai Brotherson's Le Roi absent, are especially sharp and inspiring. Different aspects of (post) colonial humour are elucidated - word play, interlingual humour, humour and the erotic, and the use of juxtaposition - and solutions to the untranslatability of humour, i.e., various ways to offer a proper translation of it, frequently as an imbalance between textual features and original context in a sort of conflict of power relations, as Tymoczko and Gentzler (2000) maintain.

In chapter eight, award-winning literary translator Peter Bush makes a carefully interesting comparison of the different edited translations into English of Juan Goytisolo's Juan sin tierra (1975), including Helen Lane's translation and his own two versions, stressing the intertextual constraints around the various processes of these translations. The translator emphasizes the necessary collaboration between editor and translator in translating for publication and the potential benefits from this interaction, especially in training literary translators. Bush concludes with the idea that translation relies on many different aspects and constraints beyond the mere linguistic and intellectual, such as nationality, socio-cultural situation, geographical area, and temporal period. He also questions some generally accepted notions such as that translation leaves no room for either improvization or variation of the author's intention, and whether we can ever really be sure of the author's intention, reminding us of the constant presence of the subjective element in a creative translation process. Unfortunately, we cannot always observe such inspiration and self-confident appreciation when we are teaching, but such is the nature of translation, at least until translation becomes a science.

Finally, in Translation, the last section of this volume, former directors of the BCLT Peter Bush, Jean Anderson, and Heike Brandt offer their respective translations of Spanish Jorge Carrión's Los muertos (“The Dead”), Tahitian Moetai Brotherson's Le Roi absent ("The Missing King”), and German Heike Brandt's Wie ein Vogel in Käfig ("Like a Bird in a Cage").

Summing up, in this volume of essays Wilson and Gerber skillfully prove their initial statement that in translation a process of "intertextual grafting" occurs, so that the work of the translator not only responds to, but also complements that of the creative writer. Hence, the different notions of "refraction," "transcreation" and "per-version" designate different means through which translations mirror "original" texts and act as "(re)creations" and transformations of the self.

We could say that "transcreation" refers to the process of creation across languages and cultures when translating a literary work, whereas "refraction" has to do with the diverging process produced while translating from one culture to another; i.e., the resultant gains and losses to the original work during the translating process (see Llácer 2004). "Writer-translation" is the process by which a literary author translates his/her own work into another language. Finally "multilingual 
creation" occurs when a bilingual author produces a version of a work which mixes at least two points of view in a bicultural product of translation.

This collective work is clearly valuable for its wisdom and insight into the exercise of translation, aptly combining a theoretical support with practical exercises on the evaluation of literary translations which should greatly assist translation lecturers and teachers. Also very important is that all contributors acknowledge the true value of translation to the literary creative process. The only objection to this kind of work is that obviously because of the nature of translation, analyses cannot always be strictly scientific since translation is not an exact science. But for the rest, I enjoyed reading this work overall and heartily recommend it to translators, researchers and scholars interested in literary translation.

Eusebio V. LlÁcer Universitat de València, Valencia, Spain

\section{REFERENCES}

Bassnett, Susan and Bush, Peter (2006): The Translator as Writer. London/New York: Continuum.

Llácer LlorCA, Eusebio Vicente (2004): Sobre la traducción: ideas tradicionales y teorías contemporáneas. Valencia: Universitat de València.

Tymoczko, Maria and Gentzler Edwin, eds. (2002): Translation and Power. Amherst: University of Massachusetts Press.

Chalvin, Antoine, Lange, Anne et MontiCELLI, Daniele (dir.) (2011): Between Cultures and Texts/Entre les cultures et les textes. Itineraries in Translation History/Itinéraires en histoire de la traduction. Frankfurt am Main: Peter Lang, $320 \mathrm{p}$.

L'ouvrage rassemble 24 des 42 contributions retenues pour la conférence qui s'est tenue à l'Université de Tallinn (Estonie) en collaboration avec le Centre d'étude de l'Europe médiane CEEM de l'INALCO (Paris) et l'Université de Tartu les 9 et 10 avril 2010. Le recueil offre un éventail large et diversifié traitant, d'une part, de l'histoire et de la théorie de la traduction et, de l'autre, de la traduction dans l'histoire.

C'est Theo Hermans qui ouvre l'ouvrage par une introduction fort intéressante qu'il titre «How is translation possible?». L'accent est mis sur la difficulté de traduire un contexte étranger. Les trois exemples d'expériences traductives («thick translation») qu'il cite représentent parfaitement ce que Leon de Kock appelle «unresolved heterogeneity» (p. 12); les écarts idéologiques rendent la tâche de traduction laborieuse et malaisée. La traduction n'enregistre pas les correspondances qui existent entre les langues et les cultures, mais elle les crée. Hermans recense ensuite les théories qui, d'après lui, participent activement à l'écriture de l'histoire de la traduction et qui sont: 1 . la théorie du polysystème d'Itamar Evan-Zohar et son structuralisme dynamique à multifacettes qui permet de mieux cerner les variables socioculturelles dans le temps et dans l'espace; 2 . la théorie de l'action de Pierre Bourdieu qui décrit les comportements des individus ou des groupes sociaux de manière rationnelle; 3 . la théorie narrative et la théorie de l'évolution avec ses trois axes: variation, sélection et stabilisation.

Les directeurs ont réparti les communications en trois blocs thématiques, allant de l'histoire de la traduction dans l'Europe médiane - à quelques exceptions près - en passant par la traduction dans l'histoire de l'Estonie, pour finir avec plusieurs études de cas à l'international. Nous reprendrons, ici, cet ordre: 1 . Théorie, méthodologie, état de la recherche (9 articles, dont 4 en français); 2. Histoire de la traduction en Estonie ( 9 articles tous en anglais); 3. Études de cas (4 articles en anglais et 2 en français). Outre son apport théorique non négligeable, ce livre est un vrai carnet de voyage traductologique en Europe médiane (Hongrie, Bulgarie, Ukraine, Slovénie et Estonie), mais qui nous emmène aussi en Italie, au Royaume-Uni, en Turquie, au Mexique et à Hong Kong.

Le premier article signé Peeter Torop «History of translation and cultural autotranslation » tente de répondre à la question: que signifie le processus de traduction du point de vue méthodologique? La notion de traduction «totale» lui est très chère. Par «totale», il entend une description exhaustive d'une langue, et ceci ne peut se faire qu'en multipliant les traductions. Certes, cela ne veut pas dire qu'on ne peut décider de privilégier une production traductive au détriment d'une autre, mais, plutôt, de chercher à comprendre quelles parties de la culture émettrice ont été traduites, et à l'inverse, quelles en sont les pertes.

Dans la deuxième communication, Christophe Rundle nous fait sortir des sentiers battus des études traductologiques ou plutôt nous fait voyager à contre-courant! Il nous invite à explorer la traduction dans l'histoire. Une invitation au voyage dans l'Italie fasciste des années 1930 et 1940 où le polar comme genre littéraire et le mouvement néoréaliste se sont propagés grâce à, ou à cause de - diraient les fascistes! - l'influence des importations littéraires étrangères qui étaient majoritairement américaines. La traduction n'était pas considérée comme une menace au fascisme, du moins pas avant 1938, date à laquelle le racisme officiel est proclamé dans l'Italie mussolinienne. 